\title{
“LIBROS PARA NIÑAS Y LIBROS PARA NIÑOS": PRESENCIA DE ESTEREOTIPOS DE GÉNERO EN UNA COLECCIÓN DE LIBROS PARA DIBUJAR
}

Yolanda Cabrera García-Ochoa

yolanda.cabrera@uem.es

Universidad Europea de Valencia
Vladimir Martínez Bello

vladimir.martinez@uv.es

Universitat de València

Recibido: 13-02-2014

Aceptado: 26-03-2014

\section{Resumen}

Los aprendizajes que se producen a partir de las propuestas imaginarias y simbólicas en los materiales didácticos pueden contener elementos sexistas. El objetivo del estudio consiste en determinar, a través de un análisis de contenido, si la colección de libros para dibujar "Doodle para niñas" y "Doodle para niños" representa roles estereotipados de género en sus imágenes y en el texto escrito. Tanto a nivel de representación gráfica como escrita, ambos libros utilizan roles estereotipados sobre todo en detrimento de la mujer. Aunque el sistema educativo español señala hace años un modelo igualitario para eliminar la discriminación, los avances conseguidos desde un prisma constitucional y legal, van muy por delante de unos sistemas culturales y sociales que apenas han evolucionado.

Palabras Clave: Libros para colorear, sexismo, educación primaria, familias

\begin{abstract}
Teaching materials promote the learning process through imaginary and symbolic proposals that may contain sexist messages. The aim of the study is to determine, through a content analysis, whether a collection of coloring books called "The Boys' Doodle Book" and "The Girls' Doodle Book" represents stereotypical gender roles in their illustrations and written text. Both in terms of images and written texts, the two books use mostly stereotyped roles to the detriment of women. Although the Spanish educational system has been working on an equality model between women and men to minimize and eliminate discrimination, progress in equality from a constitutional and legal view is well ahead of some cultural and social systems that have hardly changed.
\end{abstract}

Keywords: Coloring books, sexism, elementary education, families. 


\section{Introducción}

\subsection{Los materiales curriculares y la promoción de la igualdad entre los géneros}

Los aprendizajes inconscientes que se producen a partir de las propuestas imaginarias y simbólicas utilizadas por los textos escolares, los materiales didácticos o por el discurso utilizado por los medios de comunicación contienen elementos sexistas que se concretan fundamentalmente en la construcción de personajes femeninos asociados a papeles subsidiarios, a funciones de cuidado de los demás, como sujetos preocupados principalmente por su aspecto físico o como objetos de deseo.

El sexismo, es decir, la discriminación negativa por razón de sexo, generalmente en detrimento de niñas, jóvenes y mujeres, es una de las constantes más visibles en los modelos femeninos presentes en nuestra sociedad tanto en el discurso publicitario como en los materiales curriculares aunque siempre se pretenda encubrirla sobre la base de una falsa idealización (Cabrera, 2009).

Teóricos de la educación crítica han centrado su atención en determinar por ejemplo, cómo los materiales curriculares fomentan, exaltan o normalizan situaciones de discriminación gracias a su poder como transmisores de significados tanto en el interior de las aulas educativas como fuera de ellas (Sacristán, 1991; Giroux, 1992). Pueden ser recursos para mejorar la calidad de la enseñanza y al mismo tiempo convertirse en un recurso ineficaz, limitado y discriminatorio (Brugelles y Cromer, 2009).

Aunque el sistema educativo español hace años que trabaja sobre un modelo igualitario para minimizar y eliminar la discriminación y el sexismo, todavía presente en la sociedad, lo cierto es que, a pesar de los avances conseguidos, la visión androcéntrica y los contenidos poco actualizados de algunos materiales curriculares han tenido como consecuencia que los avances conseguidos en materia de igualdad vayan muy por delante de unos sistemas culturales y educativos que apenas han evolucionado. Más bien lo que ha ocurrido, es que las niñas han sido incorporadas plenamente al modelo educativo masculino, pero sin que éste se haya transformado como resultado de esta inclusión (Subirats, 2007). 


\subsection{Las directrices de promoción de la igualdad en los materiales curriculares}

Entre los objetivos de Desarrollo del Milenio (ODM), que derivaron de los acuerdos y resoluciones de conferencias mundiales organizadas por las Naciones Unidas en el último decenio (ONU, 2010), se destaca el objetivo número 3 que consiste en "Promover la igualdad entre los sexos y el empoderamiento de la mujer". Según la Organización de las Naciones Unidas para la Educación, la Ciencia y la Cultura el sexismo en los materiales curriculares legitima, apoya y justifica una situación de desigualdad en la que se encuentran las mujeres dentro de la sociedad (Michel, 1987; Bruguelles y Cromer, 2009).

En el plano español, el artículo 4 de la Ley Orgánica 1/2004, de 28 de diciembre, de Medidas de Protección Integral contra la Violencia de Género, señala en su artículo 6 que "Con el fin de garantizar la efectiva igualdad entre hombres y mujeres, las Administraciones educativas velarán para que en todos los materiales educativos se eliminen los estereotipos sexistas o discriminatorios y para que fomenten el igual valor de hombres y mujeres". A su vez, la Ley Orgánica 2/2006 de Educación, señala como uno de los principios y fines del sistema educativo español el fomento de la igualdad efectiva entre hombres y mujeres, y la igualdad de derechos entre hombres y mujeres y en la igualdad de trato, respectivamente.

A su vez señala como uno de los objetivos de la educación primaria en el ámbito de la igualdad entre niños y niñas, el "Desarrollar sus capacidades afectivas en todos los ámbitos de la personalidad y en sus relaciones con los demás, así como una actitud contraria a la violencia, a los prejuicios de cualquier tipo y a los estereotipos sexistas".

Por su parte, la Ley Orgánica 3/2007 señala en su artículo 24 entre otras acciones, tanto la atención especial en los currículos de todas las etapas educativas así como el principio de igualdad como la eliminación y el rechazo de los comportamientos y contenidos sexistas y estereotipos que supongan discriminación entre mujeres y hombres, con especial consideración a los materiales educativos. 


\subsection{Los libros para dibujar como materiales curriculares}

Según el informe de la Panorámica de la edición española de libros 2012 del Ministerio de Educación, Cultura y Deporte (2013), el sub-sector de "libros infantiles y juveniles" representa un $23 \%$ dentro de la distribución por materias de la cifra global de facturación por ventas en el mercado interior, aumentando sus ventas desde el año 2003. Es decir los libros didácticos para la población infantil son, por los bajos precios y las interesantes oportunidades educativas que despliegan, herramientas interesantes que sirven como puente de equilibrio entre la educación y el entretenimiento (Stokely, 2010).

A pesar de que los libros para dibujar y colorear dirigidos a población infantil han sido estudiados como elementos reforzadores de la creatividad (Randall y Draper, 1981), de la psicomotricidad y el desarrollo cognitivo, en los últimos años se han desarrollado estudios centrados en el análisis de las representaciones que promueven la discriminación y exclusión (Stokely, 2010; Fitzpatrick y McPherson, 2012).

\subsection{Estereotipos por razón de género}

Desde la conocida publicación por Weitzman y cols., (1972) y Rachlin and Vogt (1974) en la década de los setenta, así como las investigaciones realizadas en el ámbito español por Careaga, 1987, García-Gracia et al., 1993, Blanco García (2000), Instituto de la Mujer e IMOP (2000), es claro que los estereotipos de género en los materiales curriculares fomentan la discriminación entre niños y niñas incluso desde las primeras etapas del sistema educativo. Estos estudios se han centrado en conocer el contenido latente y oculto de los significados en la representación de los hombres y las mujeres con especial atención a los ámbitos sociales y profesionales. Sin embargo, para el conocimiento de quienes escriben este trabajo, tanto a nivel anglosajón como español, los estudios que intentan decodificar y criticar los significados de los libros para dibujar son escasos. Solamente se tienen en el plano internacional anglosajón los estudios de Rachlin y Vogt (1974) y Fitzpatrick y McPherson (2010) que encontraron que en el primero, los hombres fueron representados con mayor frecuencia que las mujeres, mientras que en el segundo, a pesar de la existencia de equilibrio en el número de 
imágenes pertenecientes a mujeres y hombres, observaron diferencias sobre las actividades desarrolladas por cada uno de estos grupos, especialmente frente a los roles familiares y laborales desarrollados por chicos y chicas.

\subsection{Justificación y Objetivo del estudio}

Los libros de texto, los libros infantiles y los libros para colorear y dibujar, son elementos que pueden ser analizados a la luz de parámetros que dan cuenta de la forma en que las mujeres y los hombres son representados en sus imágenes y en el texto escrito, y que llegan en muchos casos sin control alguno a las escuelas y a los hogares.

Por esa razón, el presente estudio se justifica en la medida en que es necesario desentrañar en una colección de libros para dibujar presente en el mercado nacional español, los significados ocultos y latentes de contenidos que, en principio fomentan una segregación por género hacia niños y niñas en edad escolar. Es el caso de la colección “Doodles para niñas" ( "LDA”) y “Doodle para niños" ( "LDO”), que tiene incluso desde sus portadas un tratamiento distinto en función del público al cual se dirige. Por esa razón, el objetivo del presente estudio consiste en analizar si una colección de libros para dibujar titulada “ $L D A$ ” y “ $L D O$ ” representan roles estereotipados de género en sus imágenes y en el texto escrito.

\subsection{Pregunta problema}

La pregunta de investigación que servirá como guía para el desarrollo del presente estudio consiste en: ¿Los libros “ $L D O$ ” " $L D A$ ” representan roles estereotipados de género en sus imágenes y en su texto escrito?

\subsection{Hipótesis}

De acuerdo al análisis de estudios sobre el sexismo realizados en materiales curriculares en lengua inglesa y castellana, y para facilitar la consecución de los objetivos del presente estudio, se proponen las siguientes seis hipótesis: 
Presencia de estereotipos de género en una colección de libros para dibujar

H1. La representación del género masculino y femenino será predominante en el “ $L D O$ ” y en el “ $L D A$ ”, respectivamente.

H2. Los adultos tendrán una representación mayor en el " $L D O$ ” mientras que las niñas tendrán una representación mayor en el " $L D A$ ”.

H3. El género masculino en el " $L D O$ " será representado de forma individual mientras que el género femenino en el " $L D A$ " será representado de manera colectiva.

H4. Las mujeres y los hombres serán retratados en las imágenes de los libros “ $L D O$ ” y " $L D A$ ” bajo roles estereotipados tanto a nivel de ámbito de acción como profesional.

H5. En el lenguaje escrito, los adjetivos utilizados para retratar la acción de los personajes principales tendrá una representación de roles estereotipados por género.

H6. En el lenguaje escrito, las órdenes del sujeto que debe dibujar y completar las imágenes no dependerán si el libro está dirigido a niños o a las niñas .

\section{Metodología}

\subsection{Muestra}

La unidad de muestreo para realizar el análisis de contenido fue una colección de libros para dibujar y colorear. La colección está compuesta por dos libros de la editorial Michael O`Mara Books Ltd. con traducción al castellano por parte de Libros del Atril S.L. y con ilustraciones de Andrew Pinder: "Doodles para niñas" (2010) y "Doodle para niños" (2010, a). Estos dos libros son originalmente editados en el Reino Unido y tienen presencia en el mercado español.

El criterio general para seleccionar éste texto fue que se tratase de un libro dirigido a población infantil donde el núcleo principal fuesen actividades para colorear y dibujar, y donde existiese una separación expresa de los sexos. 


\subsection{Unidades de registro}

En el presente estudio las unidades de registro que se analizan son las imágenes donde fue posible identificar personajes protagonistas y secundarios, sin ninguna distinción de edad. En el caso de existir más de dos personajes, los dos personajes con mayor participación en la acción fueron seleccionados bien, como personaje protagonista o secundario. Las imágenes que cumplieron con este criterio fueron escogidas y un grupo de observación compuesto por tres integrantes ajenos al estudio, analizaron las imágenes con base en una plantilla diseñada para tal efecto. En total se analizaron 180 personajes protagonistas y secundarios de las láminas en los dos libros para dibujar.

\subsection{Técnica de análisis}

Como previamente se señaló, el objetivo del presente estudio consiste en analizar si una colección de libros para dibujar representa roles estereotipados de género en sus imágenes y en el texto escrito. La técnica utilizada para el estudio de las imágenes fue el análisis de contenido. El análisis de contenido es una técnica cuantitativa y cualitativa que favorece el estudio de la transmisión de significados de unidades de registro (Texto escrito o imágenes) a través de una lectura con base en la construcción de un sistema de codificación de categorías e indicadores (Hsieh y Shannon, 2005).

\subsection{Sistema de categorías e indicadores}

Se adaptó un sistema de categorías e indicadores, con especial atención a la representación de personajes en las imágenes como ha sido utilizado por Careaga, 1987, García-Gracia et al., 1993, Blanco García (2000), Instituto de la Mujer e IMOP (2000). Las categorías fueron: Género y edad de los personajes, agrupación y ámbitos de acción. Los indicadores para la categoría género fueron: Masculino, Femenino y No se distingue.

Los indicadores para la categoría edad fueron: Infancia, Adolescencia, Madurez y Tercera Edad.

Los indicadores para la categoría Agrupación fueron: Hombre solo, Mujer sola, Colectivo hombre, Colectivo mujeres y Colectivo Mixto. Los indicadores para la 
Presencia de estereotipos de género en una colección de libros para dibujar

categoría ámbito de acción fueron: Científico/Técnico, Económico/Laboral, Político/Jurídico, Militar, Doméstico, Ideológico/Cultural y Deportivo/Lúdico.

\subsection{Procedimiento de recogida de datos y análisis estadístico}

Se elaboró una prueba piloto de imágenes de los dos libros que fueron discutidas a profundidad por el equipo investigador. Se analizaron los personajes y fueron descartadas aquellas imágenes donde el personaje era ambiguo, difícilmente reconocible o bien porque no aparecía figura humana alguna.

De acuerdo con Neuendorf (2011), el mínimo número de codificadores para el análisis de contenido son dos. Sin embargo, para el presente estudio y con el objetivo de garantizar la confiabilidad de las observaciones, tres personas formaron parte del grupo observacional.

El grupo observacional fue entrenado sobre las categorías e indicadores sin transmitir el objetivo o las hipótesis del estudio. Las sesiones de observación de las imágenes fueron dos, separadas por una semana, con una duración aproximada cada una de dos horas.

Cada imagen fue observada por separado mientras se completaba una plantilla. La injerencia del equipo investigador fue mínima. Se utilizó una estadística descriptiva de cada una de las categorías y para la estadística inferencial, se utilizó el estadístico chicuadrado para establecer la independencia de las categorías entre los dos libros.

Cuando no fue posible utilizar la estadística inferencial, la discusión se construyó con base en la revisión de la literatura sobre el análisis del sexismo en los materiales curriculares. Se aceptaron las diferencias con valores de probabilidad inferior a 0.05. Se utilizó el programa SPSS versión 19 para el análisis estadístico de todos los resultados. 


\section{Resultados}

\subsection{Representación del personaje protagonista según el género}

Figura 1. Representación del personaje protagonista según el género

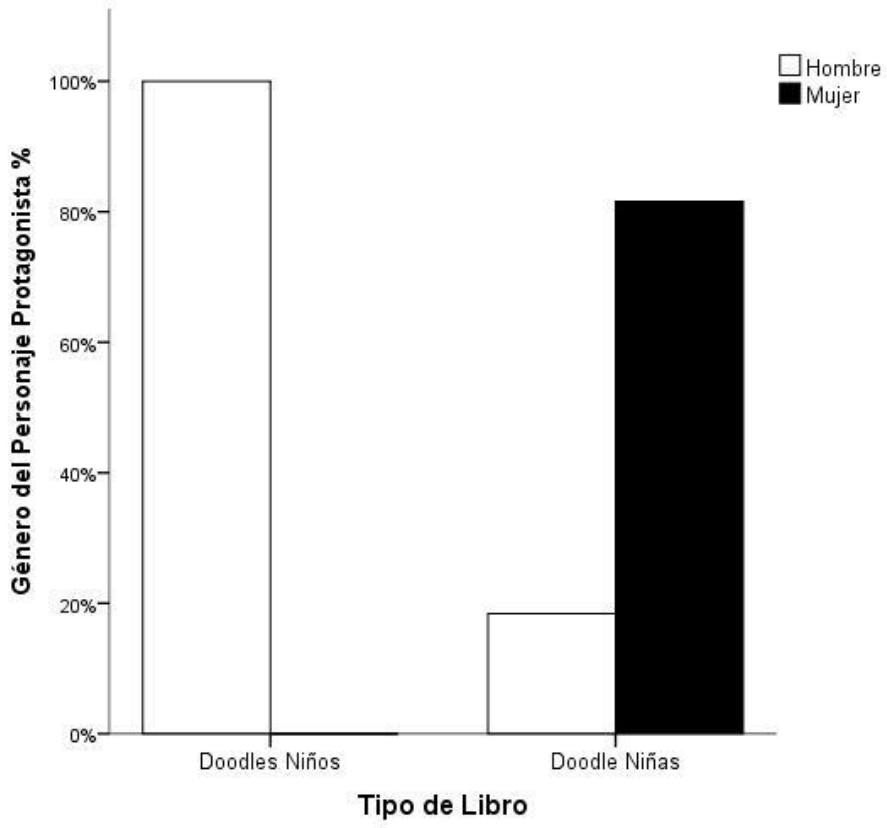

Fuente: elaboración propia.

En la figura 1 se observa en el " $L D O$ ” que el $100 \%$ de los personajes principales representados en las imágenes son hombres. Por el contrario, en el " $L D A$ ” el $80 \%$ de los personajes protagonistas corresponden a mujeres, mientras que el $20 \%$ corresponde a hombres. La prueba de Chi-cuadrado señala que la diferencia fue estadísticamente significativa: $\chi^{2}=51.4, p<0.01$. 
Presencia de estereotipos de género en una colección de libros para dibujar

\subsection{Representación del personaje secundario según el género}

Figura 2. Representación del personaje secundario según el género

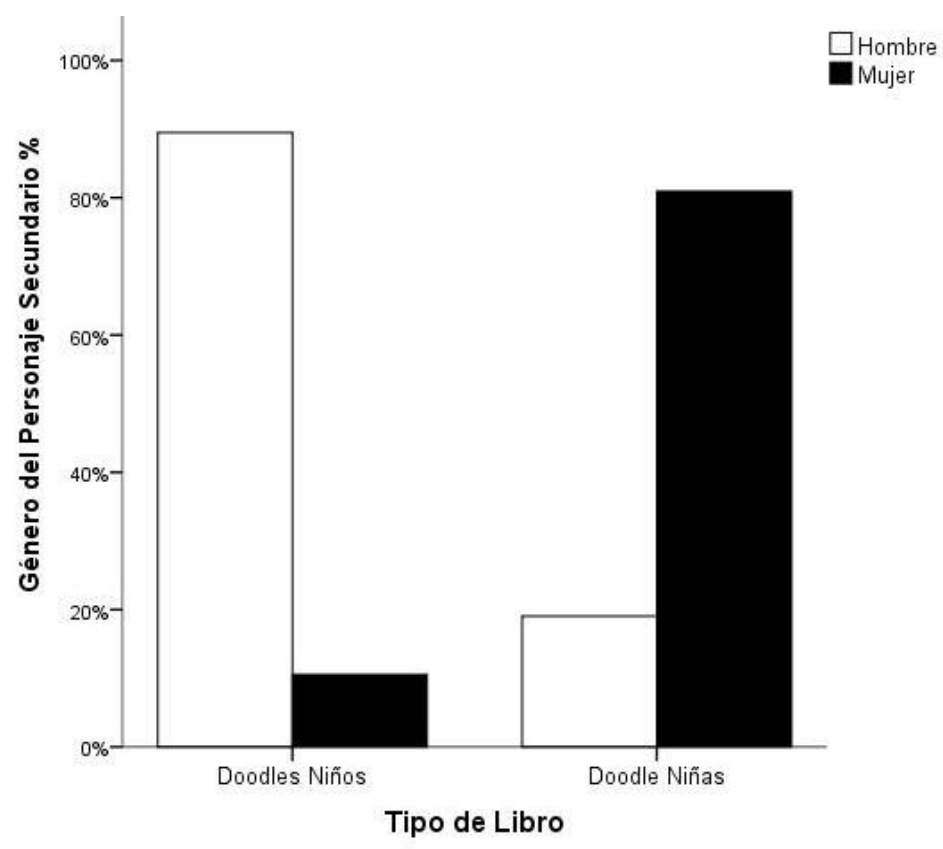

Fuente: elaboración propia.

En la figura 2 se observa en el " $L D O$ ” que el $88 \%$ de los personajes secundarios son hombres, mientras que el $12 \%$ corresponde a mujeres. Por el contrario, en el " $L D A$ ” el $81 \%$ de los personajes protagonistas corresponden a mujeres, mientras que el 19\% corresponde a hombres. La prueba de Chi-cuadrado señala que la diferencia fue estadísticamente significativa: $\chi^{2}=19.9, p<0.01$. 


\subsection{Representación de la edad del personaje protagonista}

Figura 3. Representación de la edad del personaje protagonista

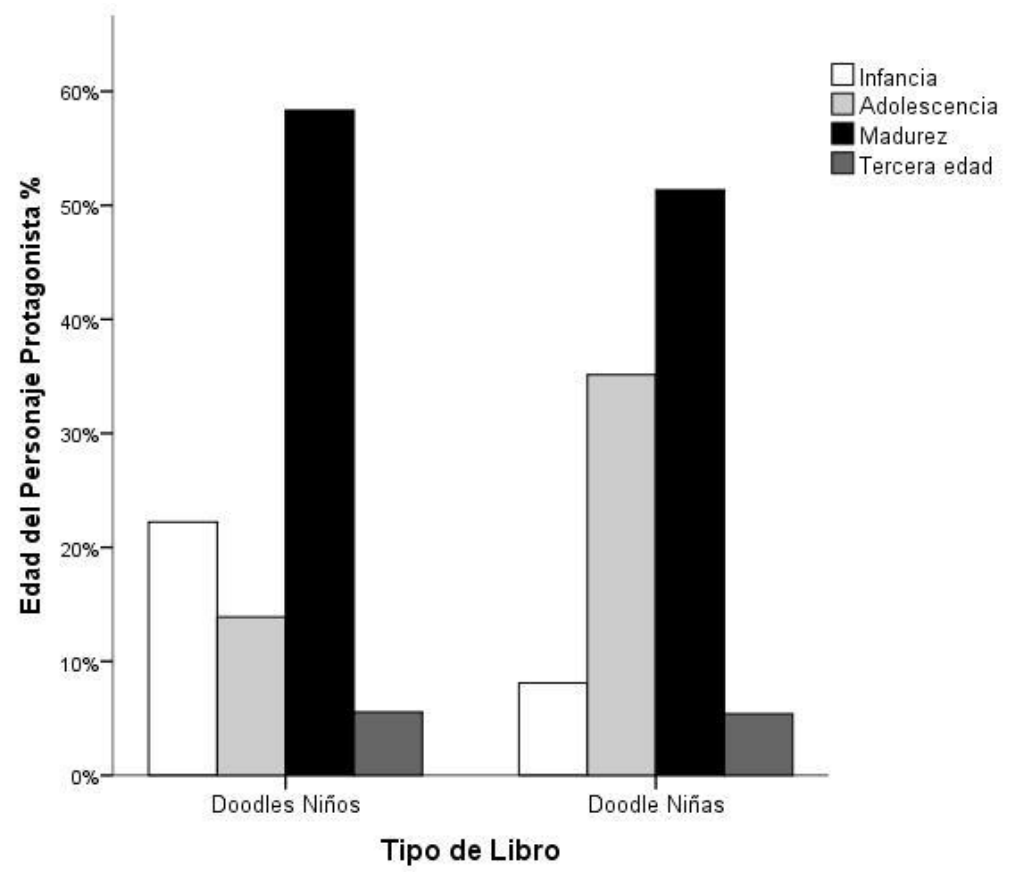

Fuente: elaboración propia.

En la figura 3 se observa en el " $L D O$ " que el indicador "Madurez" es quien tiene mayor porcentaje con un $58 \%$, seguido de "Infancia" con un $22 \%$, mientras que los indicadores "Adolescencia" y "Tercera Edad" fueron representados un 14\% y 6\%, respectivamente. Por su parte, en el " $L D A$ ” el $52 \%$ de los personajes protagonistas representan el indicador "Madurez", seguido de "Infancia" con un $8 \%$, mientras que los indicadores "Adolescencia" y "Tercera Edad" fueron representados con un $36 \%$ y $4 \%$, respectivamente.

Al combinar los indicadores "Infancia" y "Adolescencia", la representación de estos indicadores en el " $L D A$ " corresponde al 44\%, mientras que en el " $L D O$ " estos corresponden al $34 \%$. Sin embargo, al aplicar la prueba de Chi-cuadrado con el fin de estudiar la asociación entre la variable Edad y Tipo de Libro, no se observaron diferencias estadísticamente significativas: $\chi^{2}=5.91 p=0.2$. 


\subsection{Representación de la edad del personaje secundario}

Figura 4. Representación de la edad del personaje secundario

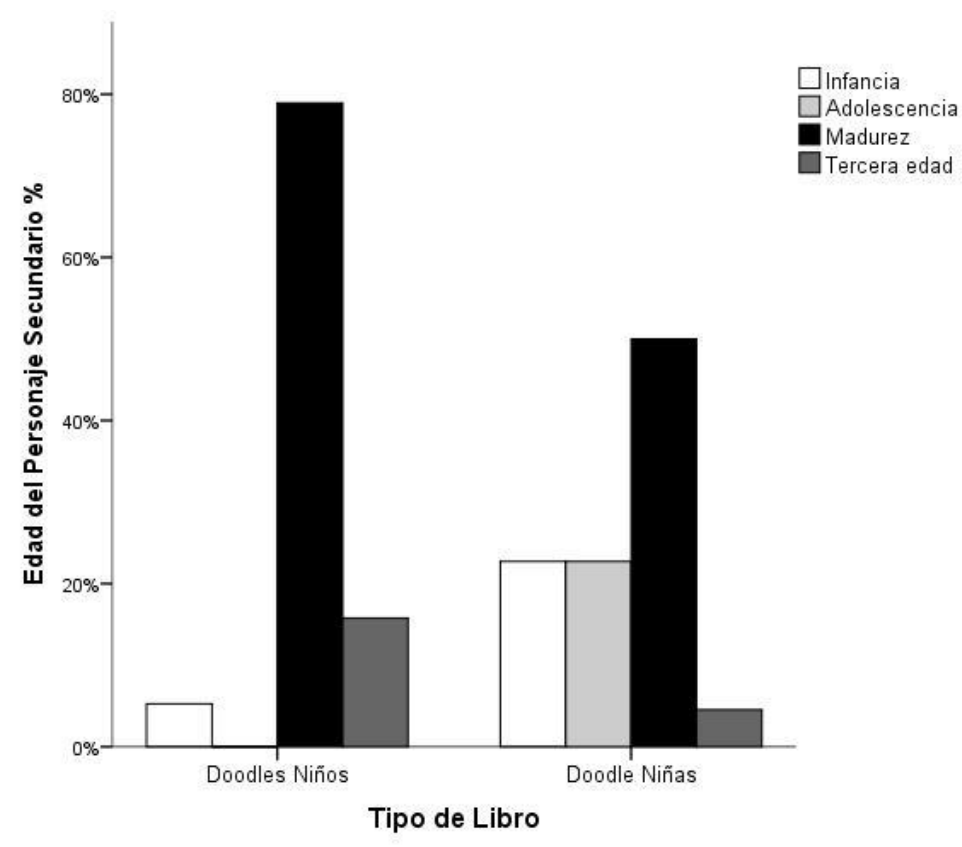

Fuente: elaboración propia.

En la figura 4 se observa en el "LDO" que el indicador "Madurez" corresponde al $79 \%$, mientras que los indicadores "Tercera Edad" e "Infancia" fueron representados con un $16 \%$ y $5 \%$, respectivamente. Por su parte, en el " $L D A$ " el $51 \%$ de los personajes secundarios representan el indicador "Madurez", seguido de "Infancia" y "Adolescencia" con un 22\% para ambos, mientras que el indicador "Tercera Edad" correspondió al 4\%.

Al combinar los indicadores "Infancia" y "Adolescencia", la representación de estos indicadores en el " $L D A$ " corresponde al $44 \%$, mientras que en el " $L D O$ " estos corresponden al 34\%. Al aplicar la prueba de Chi-cuadrado con el fin de estudiar la asociación entre la variable Edad y Tipo de Libro, se observó una tendencia hacia la asociación entre las dos categorías: $\chi^{2}=9.38 p=0.6$, pero de la cual no se asume una diferencia estadísticamente significativa. 


\subsection{Representación de la forma en que se agrupan los personajes}

Figura 5. Representación de la forma en que se agrupan los personajes

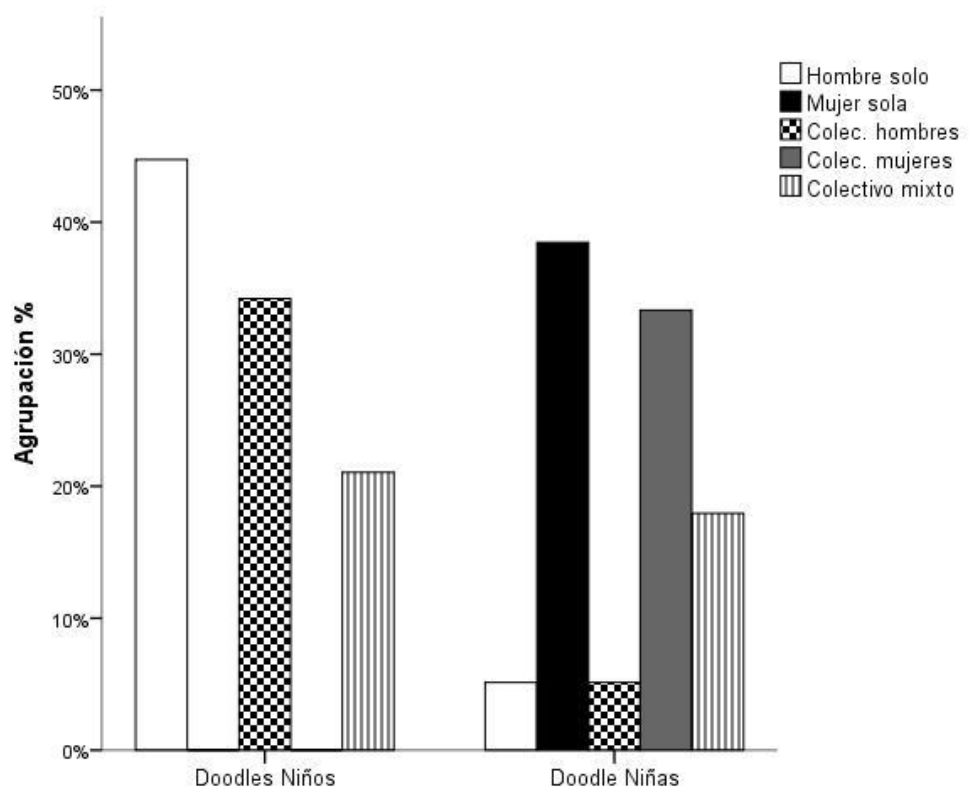

Fuente: elaboración propia.

En la figura 5 en el " $L D O$ ” el indicador con mayor presencia (44\%) es "Hombre solo", seguido de "Colectivo hombres" (34\%) y "Colectivo mixto" (22\%). Por el contrario, en el " $L D A$ " el 38\% corresponde al indicador "Mujer sola", seguido de "Colectivo mujeres" con un 34\%, mientras que el "Colectivo mixto" representó al 18\% de las imágenes. Los indicadores "Hombre solo" y "Colectivo hombres" representaron el $5 \%$ cada uno.

Mientras que en el " $L D O$ ” no se observan mujeres ni solas ni acompañas de otras mujeres, en el " $L D A$ ” los hombres, solo o acompañados de otros hombres, representan el $10 \%$ de las imágenes. La prueba Chi-cuadrado señala una diferencia estadísticamente significativa sobre la distribución de los indicadores de la variable "Agrupación” frente a la categoría Tipo de libro $\chi^{2}=47.97 p<0.01$. 
Presencia de estereotipos de género en una colección de libros para dibujar

\section{6. Ámbito de acción del personaje protagonista según el género}

Figura 6. Representación del ámbito de acción del personaje protagonista según el género

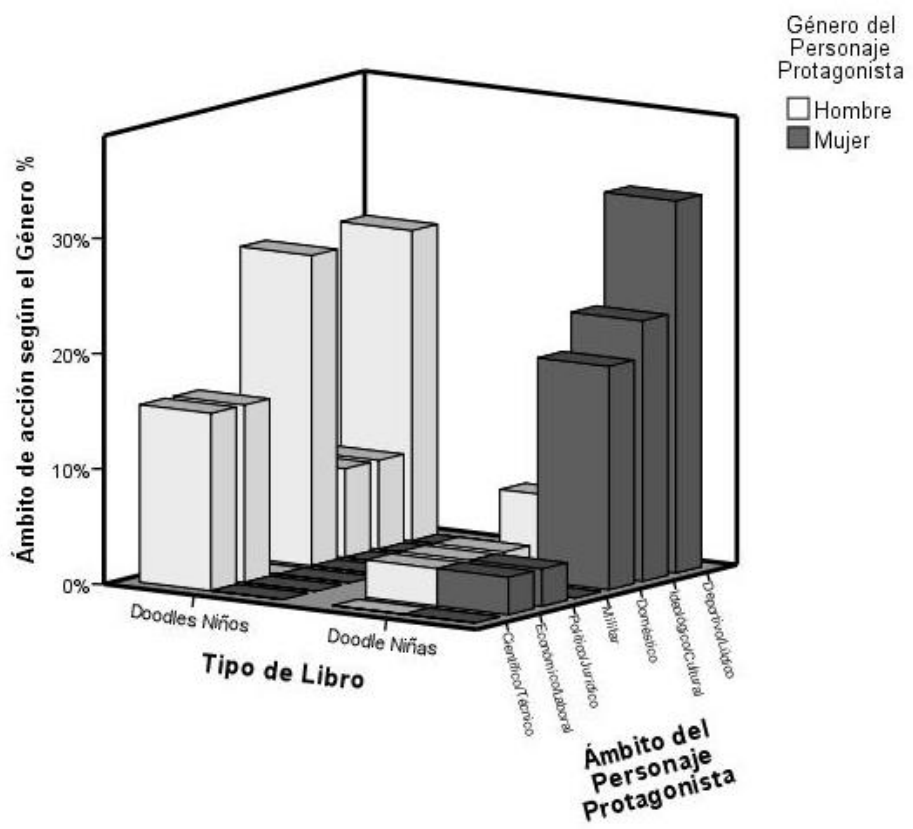

Fuente: elaboración propia.

En la figura 6 se observa en el " $L D A$ ” que las mujeres son quienes tienen la mayor representación bajo el indicador "Deportivo/Lúdico" con un 20\%, seguido por el indicador "Ideológico/Cultural con un 12\% y el indicador "Doméstico" con un 10\%. La participación de los hombres en actividades profesionales no supera el $10 \%$. Por el contrario, en el " $L D O$ ” las mujeres no son representadas como personajes protagónicos y no se puede deducir su profesión.

Sin embargo, los ámbitos de acción de los hombres en este libro, son representados en los indicadores "Deportivo/Lúdico" y "Militar" con un 30\%, respectivamente, mientras que los indicadores “Científico/Técnico" y "Económico/Laboral" son representados con un $17 \%$, respectivamente. 


\section{7. Ámbito de acción del personaje secundario según el género}

Figura 7. Representación del ámbito de acción del personaje secundario según el género

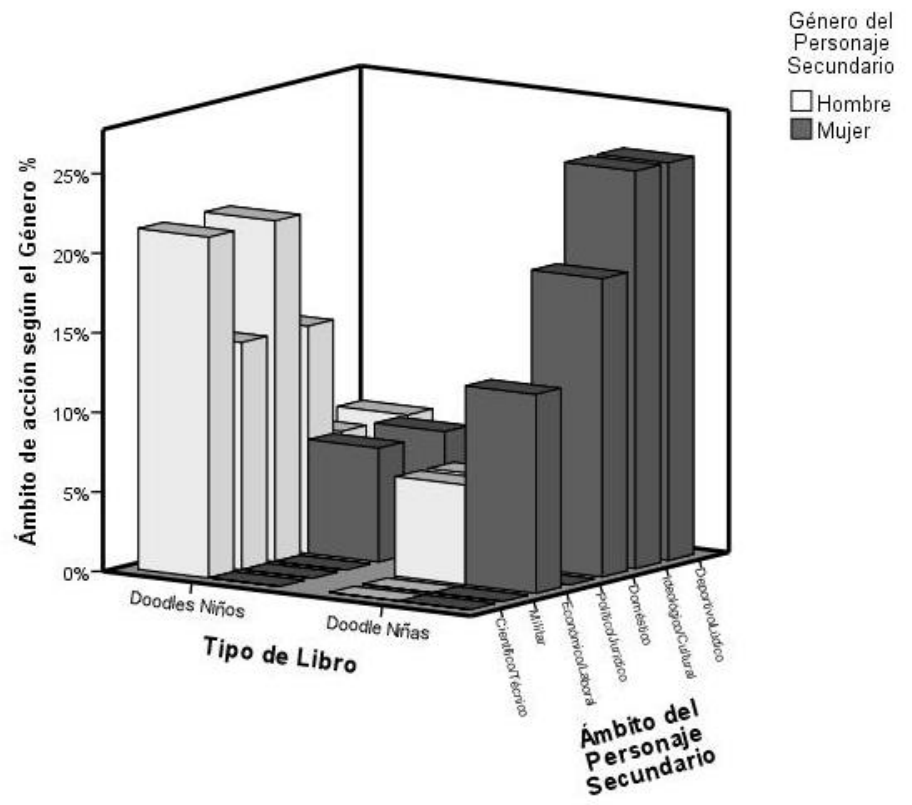

Fuente: elaboración propia.

En la figura 7 se observa que en el " $L D A$ ” las mujeres son representadas bajo los indicadores "Deportivo/Lúdico" e "Ideológico/Cultural" con un 27\% respectivamente, seguido del indicador "Doméstico" con un $18 \%$ y con $13 \%$ el indicador "Económico/Laboral". Los ámbitos de acción de los hombres como personajes secundarios no superan el $10 \%$ en ningún indicador.

Por el contrario, en el “ $L D O$ ” los ámbitos de acción más representados por los hombres son el "Científico/Técnico" y el "Económico/Laboral" con un 22\% respectivamente, seguido de los indicadores "Militar" y "Político/Jurídico" con un 14\% respectivamente. Los ámbitos de acción de las mujeres en este libro no superan el10\%. 


\subsection{Profesiones en los dos libros}

Figura 8. Representación de las profesiones en los dos libros

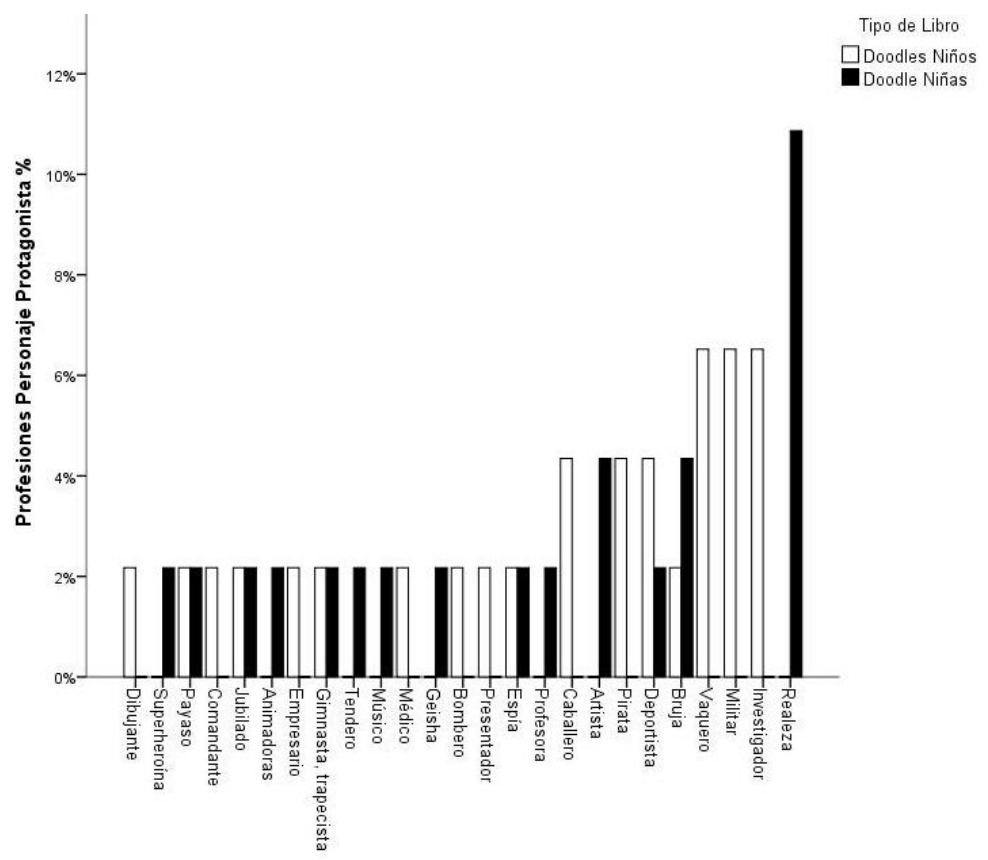

Fuente: elaboración propia.

En la figura 8 se observan que las profesiones que tienen mayor presencia en el " $L D A$ " son aquellas vinculadas con la realeza, las brujas o hechiceras y artistas. Por el contrario, las profesiones que tienen mayor presencia en el "LDO", son de investigadores, militares, vaqueros, caballeros y piratas.

Además, profesiones como investigador, médico, empresario, dibujante, comandante, bombero, presentador y caballero solo están presentes en el " $L D O$ ”, mientras que profesiones como músico, animadoras, tendero/a, profesora, super-heroína y Geisha solo están presentes en el " $L D A$ ”. 
Figura 9. Representación de las profesiones según el género

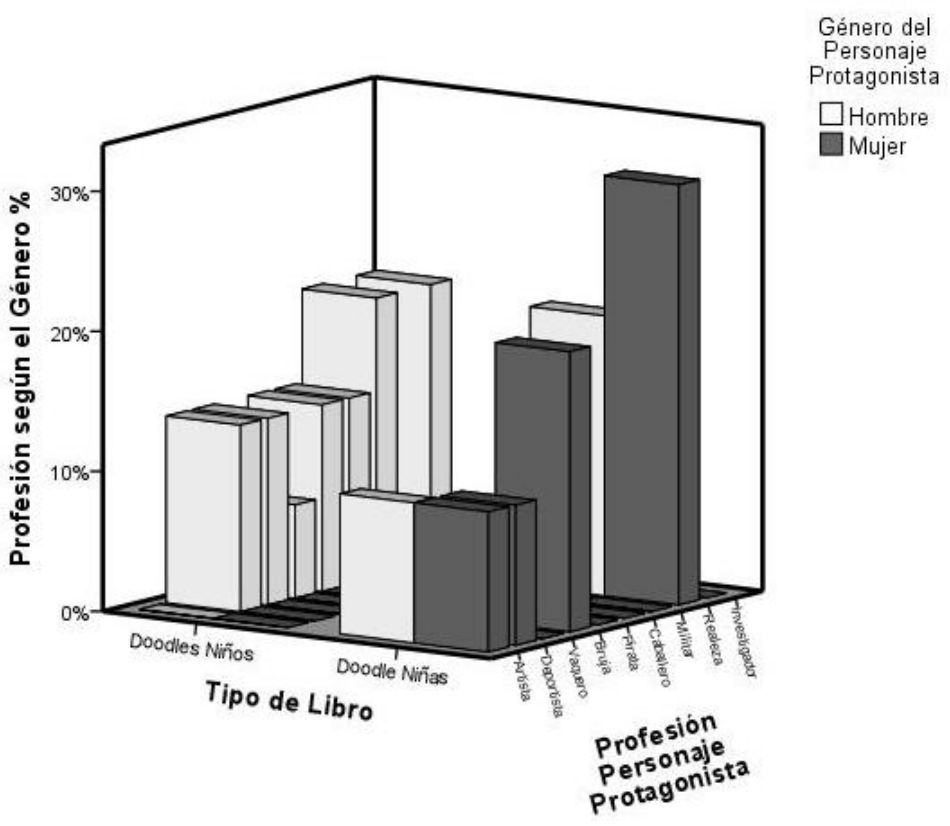

Fuente: elaboración propia.

En la figura 9 se observa que en el " $L D A$ " las mujeres son representadas en mayor porcentaje en profesiones vinculadas al indicador "Realeza", seguida de "Bruja", "Deportista" y "Artista". Los hombres son representados mayoritariamente en este libro en profesiones vinculadas a los indicadores "Realeza" y "Artista".

Por el contrario, en el " $L D O$ ” los hombres son mayoritariamente representados bajo los indicadores de profesiones como "Investigador" y "Militar", seguido de "Caballero", "Pirata", "Vaquero" y "Deportista". Al no existir mujeres como Personajes protagonistas o secundarios no se pueden analizar las profesiones. 


\section{9. Órdenes de quien debe completar la imagen en los dos libros para dibujar}

Figura 10. Presencia de órdenes de quien debe completar la imagen

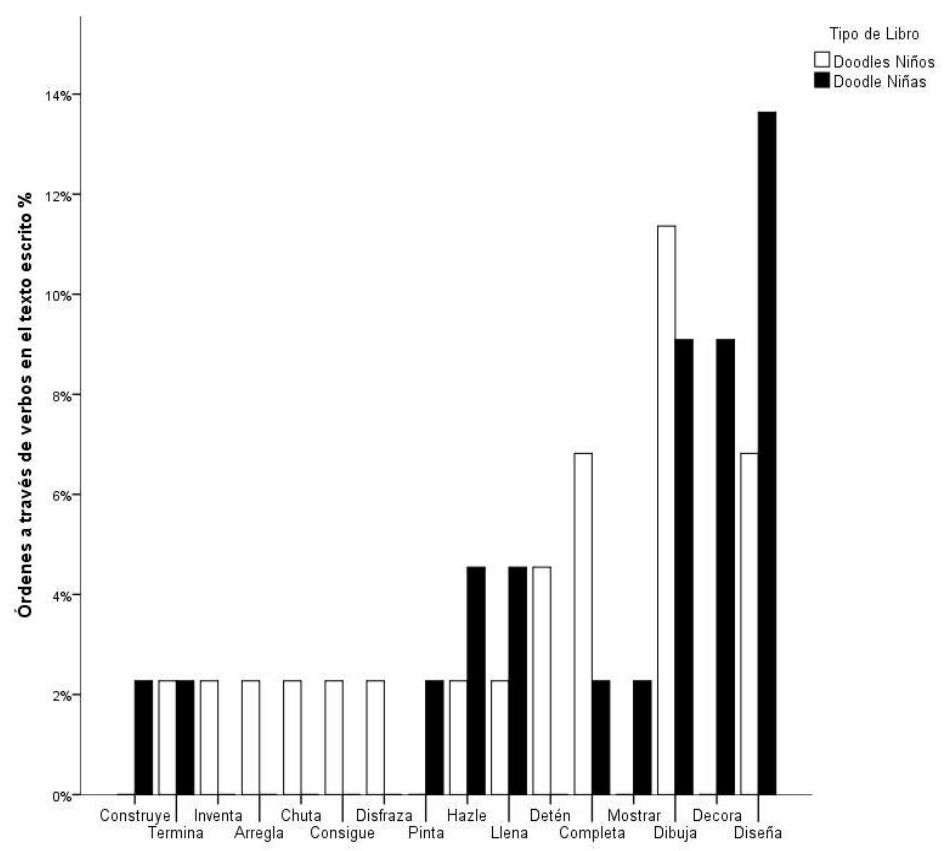

Fuente: elaboración propia.

En las láminas que representan personajes protagonistas se analizaron en el texto escrito los verbos que acompañan las imágenes y que señalan acciones para completar mediante el dibujo, las imágenes incompletas.

Como aparece reflejado en la figura 10 se observa que el verbo "Dibujar", “Completar" e "Inventar", entre otros, tienen una mayor representación en el " $L D O$ ”, mientras que los verbos "Diseñar", "Decorar", "Hacer" y "Llenar" tienen una representación mayor en el “ $L D A$ ”. 


\subsection{Adjetivos más frecuentes en los dos libros según el género}

Tabla 1. Presencia de adjetivos según el género

\begin{tabular}{|c|c|c|c|}
\hline \multicolumn{2}{|c|}{ Doodles para niños } & \multicolumn{2}{c|}{ Doodles para niñas } \\
\hline Género del personaje protagonista & \multicolumn{2}{c|}{ Género del personaje protagonista } \\
\hline Masculino & Femenino & Masculino & Femenino \\
\hline Moderno & - & - & Moderno \\
\hline Fantástico & - & - & Grande \\
\hline Dulces & - & - & Ostentosa \\
\hline Caro & - & - & Paradisíaca \\
\hline Escalofriante & - & - & Espeluznante \\
\hline Increíble & - & - & Rápido \\
\hline & & - & Espectacular \\
\hline & & Funk & Digno \\
\hline
\end{tabular}

Fuente: elaboración propia.

En las láminas que representan personajes protagonistas se analizaron en el texto escrito los adjetivos que acompañan a las imágenes y que otorgan una cualidad a la acción desarrollada por el personaje protagonista. En la Tabla 1, se observa la distribución de los adjetivos que señalan una desigual distribución de las acciones desarrolladas por hombres y mujeres en cada uno de los libros.

\section{Discusión}

Según el último informe de la Panorámica de la edición española de libros 2012 del Ministerio de Educación, Cultura y Deporte (2013), señala al sub-sector de "libros infantiles y juveniles" con un 23\% dentro de la distribución por materias de la cifra global de facturación por ventas en el mercado interior situando el precio medio se situó en 9 euros. Es decir, este tipo de libro tiene tanto por facilidad de adquisición como por su reducido precio, unas características que generan una gran acogida en el mercado español.

En líneas posteriores y para facilitar la interpretación y discusión de los resultados encontrados, cada una de las categorías utilizadas se analizará por separado. 
Presencia de estereotipos de género en una colección de libros para dibujar

\subsection{Representación del personaje protagonista y secundario en las imágenes según el género}

En el ámbito español cuando se ha investigado sobre el sexismo en los materiales curriculares se ha tomado como punto de referencia para el análisis, el personaje (GarcíaGracia et al., 1993). Siguiendo a Garreta y Careaga (1987) se entiende por protagonismo principal lo que representa un personaje cuando está claramente en la ilustración en función de protagonista, a diferencia de otros que lo acompañan y no participan de la misma manera que él-ella en la acción, narración o descripción de lo que fuere. Por personaje secundario, se refiere a aquel que actúa como mero acompañante o espectador.

De acuerdo a los resultados, la representación de personajes protagonistas y secundarios es diferente entre los dos libros. Como se observa en la figura 1, en el " $L D O$ " es el género masculino quien dirige, coordina y monopoliza la totalidad de las imágenes de los personajes en las imágenes. Es decir, son los hombres o los niños para quienes las actividades $\mathrm{u}$ acciones representadas en las imágenes son dirigidas, negando por el contrario a las mujeres roles o actitudes de participación activa en este libro.

Por el contrario, en el " $L D A$ " la acción o actividad recae de forma significativa en el género femenino. Bajo la misma línea, la representación del género masculino o femenino como personaje secundario recibe el mismo tratamiento en los dos libros para dibujar. La figura 2 señala que los hombres y los niños también tienen una mayor representación como personajes secundarios en el " $L D O$ ”, mientras que las mujeres y niñas tienen una representación mayor en el " $L D A$ ”.

En dos de los pocos estudios que han analizado el contenido de las imágenes en libros para dibujar y colorear en el ámbito anglosajón, Rachlin y Vogt (1974) y Fitzpatrick y McPherson (2010) estudiaron la representación del género masculino y femenino. En el primero, los hombres fueron representados con mayor frecuencia que las mujeres, mientras que en el segundo, a pesar de la existencia de equilibrio en el número de imágenes pertenecientes a mujeres y hombres, observaron diferencias sobre las actividades desarrolladas por cada uno de estos grupos, especialmente frente a los roles familiares y laborales desarrollados por chicos y chicas.

En uno de los primeros estudios realizados hace casi tres décadas en España sobre la transmisión de significados en materiales curriculares, Garreta y Careaga (1987) 
observaron una distribución desigual de la representación en los papeles protagónicos y secundarios de hombres y mujeres en libros de texto de las áreas de Lenguaje y Ciencias Sociales de la Enseñanza General Básica. Señalan que el 66\% corresponde a personajes masculinos mientras que el $26 \%$ corresponde a personajes femeninos. A su vez, el segmento poblacional en el caso del género femenino corresponde a niñas, mientras que las ilustraciones representan al género masculino en edad adulta.

García-Gracia et al., (1993) encontraron que tanto las protagonistas como secundarias no superaron el $10 \%$ de las imágenes analizadas, mientras que el género masculino fue ampliamente representado. De igual manera, Blanco García (2000) observó que el $50 \%$ de los personajes protagonistas corresponden al género masculino mientras que el género femenino corresponde únicamente al $26 \%$.

Se observó una tendencia a que las mujeres aparecen en edad juvenil, mientras que los hombres son adultos. El Instituto de la Mujer (Ministerio de Asuntos Sociales, España) en el año 2000 encontró que en libros de texto de educación primaria de distintas áreas de conocimiento publicados entre 1993 y 1999, casi la mitad de los mismos representan como personaje principal al género masculino, mientras que solo el $26 \%$ corresponde a personajes femeninos (Instituto la Mujer, 2000).

Recientemente, Terrón-Cano y Cobano-Delgado (2008) observaron en libros de texto españoles de primaria una representación inferior de las mujeres frente a los hombres, resultado corroborado en un estudio comparado frente a libros marroquíes (Terrón-Cabo y Cobano-Delgado, 2009). A su vez, Pellejero-Goñi y Torres-Iglesias (2011) encontraron en libros de texto de matemáticas y conocimiento del medio en el primer curso de primaria que las mujeres también fueron representadas en menor proporción que los hombres.

Y en el ámbito de la educación física para secundaria, Taboas-Pais y Rey-Cao (2012) en observaron una representación mayor en las imágenes de los hombres frente a las mujeres. Por el contrario, la representación se mantiene una representación equilibrada entre el género masculino y femenino tanto en libros de texto españoles de educación infantil para niños y niñas de 3 años, (Martínez-Bello, 2013) como para libros de texto colombianos para niños y niñas del grado de Jardín (4 años) (Martínez-Bello, 2013a). 


\subsection{Representación de la edad del personaje protagonista y secundario}

Respecto a la edad de los personajes representados en las imágenes, se quiso determinar cuál es la edad y su relación con el género. Se observó (Figuras 3 y 4) que cuando en el " $L D O$ " existe un porcentaje absoluto del género masculino como protagonista éste hace relación a un hombre adulto. Por el contrario, en el " $L D A$ " cuando a pesar de una presencia mucho mayor del género femenino en sus imágenes, la edad de los personajes (protagonista y secundario) tiene una tendencia a representar más a los indicadores de "Infancia" y "Adolescencia" (25\% y 25\%, respectivamente), mientras que en el “ $L D O$ ” estos mismos indicadores para el personaje protagonista y secundario corresponde al $18 \%$ y $2 \%$, respectivamente.

En cualquier caso, se considera, tal como señalaron el Instituto de la Mujer e IMOP (2000), que el mundo infantil y sus posibilidades aparece representado como espacio y terreno del género femenino mientras que el mundo adulto aparece representado a través de la figura del hombre.

La personificación masculina que se observa en los materiales curriculares debe entenderse como un modelo sociocultural que tiene tanto forma y figura, como de actitudes y aptitudes hacia los otros y las cosas, dentro de un mundo para hombres y de hombres. Pero no solo esta observación es válida en el presente estudio. La situación se agudiza cuando la representación preferente tanto de las personas principales como secundarios está ligada hacia un público bien sea de niños o de niñas.

Es decir, la abrumadora presencia de personas protagonistas masculinos en el libro para niños sumado a la inexistente presencia de mujeres en papeles protagónicos y secundarios posiciona al hombre que es visto por los niños como un modelo imperante que es capaz de asumir profundas e importantes tareas, mientras que la mujer es representada en papeles secundarios. De la misma forma, la presencia casi total de mujeres como personajes principales y secundarios en el " $L D A$ ” refuerza como se verá más adelante que las niñas y mujeres también son protagonistas o personajes principales pero de actividades bien distintas de las señaladas para los hombres en el “ $L D A$ ”. 


\subsection{Representación de individual y/o colectiva del género masculino y femenino}

La mayoría de estudios sobre la transmisión de significados sexistas realizados en España en libros de texto, han señalado que además de la baja representación de las mujeres en las imágenes, cuando éstas son representadas, lo hacen acompañadas por otras mujeres. De la misma forma, cuando los hombres que son mayoría son representados, lo hacen más a título individual (Instituto la Mujer, 2000; Blanco García, 2000). Una de las razones esgrimidas por los grupos de investigación a la luz del análisis crítico, es que las imágenes señalan que las mujeres no tienen la suficiente autonomía para desplegar las actividades de la vida diaria y por eso son retratadas acompañadas de otras mujeres y hombres, mientras que por el contrario el hombre, que siempre ha contado con la aprobación social de valerse por sí mismo y ser el sustento de la familia, es retratado en las imágenes de manera individual. Los resultados del presente estudio indican que en la colección de libros analizados la forma en que se agrupan los personajes, sean a nivel protagónico o secundario, no difiere si éstos son dirigidos a las niñas o a los niños (Figura 5). Es decir, tanto el hombre tiene una representación mayor en el " $L D O$ " tanto de forma individual como colectiva, mientras que la mujer tiene una representación mayor en el " $L D A$ " tanto de forma individual como colectiva. No obstante la observación anterior, en los dos libros sí hay representación del colectivo mixto, pero en el " $L D A$ ” existen también imágenes con hombres como personajes representados de forma individual y colectiva, mientras que las mujeres bajo esta misma situación no son representadas en el " $L D O$ ”.

\subsection{Representación de la forma en que se agrupan los personajes}

En lo que respecta a la forma en que aparecen agrupados los personajes, según el libro en el que se encuentran, resulta sorprendente que en el volumen dirigido a los niños no aparecen mujeres ni solas ni como colectividad lo cual impide encontrar protagonistas femeninas en un material considerado masculino. Se refuerza así una visión androcéntrica del mundo al evidenciar esta exclusión total de las mujeres e incluirlas solo en colectivos mixtos en los que nunca ocupan una posición protagonista sino que aparecen en papeles secundarios o en categorías profesionales de rango inferior 
Presencia de estereotipos de género en una colección de libros para dibujar

y formando parte de una pareja o de un conjunto. Es como si de alguna manera las actividades realizadas por niñas, chicas o mujeres no tuvieran cabida en un libro que se dirige, principalmente, a entretener y formar lúdicamente a los futuros hombres.

\subsection{Representación del ámbito de acción del personaje protagonista según el género}

Los papeles y ámbitos de acción de los personajes protagonistas en ambos casos responden a una masculinidad y feminidad estereotipada y tradicional que refuerza la idea de que el mundo, es movido y dirigido por los hombres, ya que éstos ocupan los ámbitos más prestigiosos, activos y relevantes desde el punto de vista económico-político. Mientras las féminas se agrupan mayoritariamente en ámbitos de acción menos valorados socialmente, domésticos-familiares y no aparecen en categorías de producción científica o de habilidades técnicas ni en campos bélicos o asociados a los cuerpos de seguridad y defensa. Además no podemos obviar el hecho relevante de no encontrar protagonistas mujeres en el material pensado para el entretenimiento de los niños.

Encontramos una clara división y desigualdad de género en la representación de los mundos según los protagonistas y los ámbitos utilizados en cada uno de los manuales atendiendo al tipo de interlocutor/a al que se dirigen. De manera que prevalece la representación doméstica y cultural artística en las láminas protagonizadas por el género femenino mientras en el caso masculino hay un empate en la representación mayoritaria del ámbito militar y del deportivo lúdico al aparecer muchos personajes del mundo del espectáculo y los deportes. Pero se produce, entre los protagonistas masculinos, una representación más equilibrada en el " $L D O$ ” ya que a excepción de la categoría político-jurídica todas las demás aparecen representadas y las segundas en importancia corresponden al ámbito económico/laboral y el científico/técnico reflejando así esa mayor exposición pública de los personajes protagonistas masculinos mientras las protagonistas femeninas en muchas ocasiones reducen su representación a un ámbito doméstico o familiar.

En el caso de los protagonistas masculinos que encontramos en el " $L D A$ ", los personajes aparecen en casi todos los ámbitos de representación a excepción del campo científico/técnico, y el ideológico/cultural las categorías más valoradas y que representan de una forma más clara el mundo público y las cúpulas dirigentes en las que los hombres aparecen 
en las representaciones mejor consideradas. En el resto de categorías, la aparición es paritaria no destacando ninguna por encima de las otras.

\subsection{Representación del ámbito de acción del personaje secundario según el género}

En lo que respecta a los ámbitos de representación de los personajes secundarios, podemos aquí ampliar el espectro de análisis al encontrar ya en ambos libros personajes secundarios hombres y mujeres. Una vez más el ámbito cultural y de las ideas aparece, en ambos libros, mayoritariamente poblado por personajes femeninos y encontramos una clara y significativa ausencia de hombres en el ámbito doméstico, en el " $L D A$ ”.

De nuevo, en el libro para niñas, se echa en falta la representación de mujeres en los ámbitos mejor valorados socialmente con nula presencia en el área científico /técnico, militar y político jurídico. Sin embargo, vuelven a aparecer ampliamente representadas en el ámbito doméstico, cultural y deportivo lúdico.

Esta separación sexuada de los ámbitos hace una evidente separación entre el mundo público, más valorado, y el mundo privado relacionado con lo doméstico. Advierte igualmente que las parcelas de realidad ligadas a lo intelectual están mucho más presentes que las que hacen referencia a lo manual (Blanco, 2003).

\subsection{Representación de las profesiones en los dos libros para dibujar}

En lo referido a la representación de las profesiones y las diferencias observadas en los dos libros destacar el hecho relevante de que los personajes mayoritarios en el libro para niñas pertenecen a la realeza. Reyes, príncipes y princesas pero sin presencia de reinas o con ausencia de elementos que destaquen la posición de poder en el caso de las princesas (cetros de mando, escudos, capas, armas, joyas) y recurriendo a elementos más en su función ornamental (coronas, trajes suntuosos, velos, flores). Sin embargo en las láminas para niños las profesiones mayoritarias son investigadores, militares y vaqueros, tres perfiles muy diferentes pero con algunas características en común como el hecho de ser profesiones muy activas, ser bien valoradas socialmente al encargarse de la evolución y mejora de la calidad de vida y la defensa de los pueblos y en los tres casos ser productores y generadores de riqueza: conocimiento, protección, bienes de consumo (leche, carne, cuero). 
Presencia de estereotipos de género en una colección de libros para dibujar

La profesión de bruja/o cuantitativamente, aunque aparece en los dos libros, dobla en número de apariciones su presencia en el “ $L D A$ ”. Y los personajes masculinos que aparecen en este rol son considerados en la valoración del grupo observacional como magos o científicos. También físicamente la caracterización de los personajes difiere notablemente si son hombres o mujeres. En el caso de las brujas su aspecto físico es más desagradable.

Coincidimos aquí con las conclusiones del estudio de Gutiérrez Sánchez (2012), que ha analizado el material didáctico que se utiliza en los libros de texto, y constatamos que en lo que a la representación de las profesiones se refiere "el género femenino es mostrado con más frecuencia en el ámbito doméstico, cultural-artístico (más como consumidoras que como productoras), económico (generalmente realizando actividades de consumo de bienes) y religioso, mientras el masculino se dedica a la política, la cultura y la producción científica" Gutiérrez Sánchez (2012: 29).

A lo largo de las páginas se transmiten estereotipos de género que refuerzan la desigualdad y muestran algunas profesiones como más o menos aptas para hombres y mujeres. Es el caso de profesiones como bomberos o militares donde la fuerza física ha hecho que tradicionalmente los hombres copen estas profesiones. De la misma manera, los dirigentes, los emprendedores, los creativos, los líderes de opinión e incluso si lo llevamos al terreno infantil, los malos, todos están presentes en el libro para niños. Aunque estos libros de actividades pueden parecer poco relevantes a la hora de orientar profesionalmente a los niños y niñas que los completan, su visión sesgada y sexista del espectro y las salidas profesionales dirigidas a cada género limitan las expectativas que cada grupo puede tener con respecto a su futura vocación.

Este mecanismo de transmisión de valores supone una clara limitación para las expectativas laborales de las chicas, que no encuentran modelos ni referentes en los libros en los que, se supone, aprenden cuál será su papel en la sociedad en la que viven. Los chicos, en cambio, pueden verse reflejados en todas las profesiones, circunstancias y situaciones y su futuro parece, según estos libros, abierto a todas las posibilidades sin que tengan que realizar ningún esfuerzo mental para sentirse incluidos y referenciados en un abanico cultural y profesional claramente masculinizado (Peñalver, 2003). Porque no se puede olvidar que es durante la adolescencia cuando se buscan "espejos donde reflejarse" y en los libros de texto para las chicas lo que hay son espejismos. 
Encontramos otras categorías presentes en ambos libros es el caso de los jubilados/as, payasos, gimnastas, trapecistas y espías. Los primeros, fuera de la vida laboral, y el resto de categorías muy vinculadas al mundo del espectáculo o del deporte y que corroboran el hecho de que uno de los ámbitos mayoritariamente representados fuera el deportivo/lúdico. Es decir, las mujeres en el " $L D O$ ” no solo son silenciadas como personajes protagonistas o secundarias, negando por tanto que puedan ser por ejemplo, "inventoras", "científicas" y "constructoras", y de esta manera es el hombre el modelo dominante que sirve de ejemplo para los niños quienes son a los que va dirigido éste libro. De la misma forma, y a pesar de que las mujeres sí son representadas como personajes protagonistas o secundarias en el " $L D A$ ”, el ámbito de acción donde las mujeres son investigadoras, científicas o constructoras es nula, pero sí se desenvuelven en el ámbito deportivo-lúdico y doméstico.

En muchos estudios se ponen de manifiesto estas diferencias en el tratamiento y la representación de hombres y mujeres y se constatan los desequilibrios al reforzar las acciones y los méritos conseguidos por el colectivo masculino en ocasiones invisibilizando los realizados por sus homólogas. Atendiendo a las conclusiones del trabajo realizado por Judith Gutiérrez Sánchez, que analiza la presencia en los materiales escolares de hombres y mujeres, podemos afirmar que "Si nos enseñan una visión del el mundo sin mujeres, un mundo repleto de protagonistas masculinos que realizan grandes descubrimientos y hazañas para la humanidad, nos están enseñando un mundo en el que la mujer no cuenta. Y no es justo que nos despojen de nuestra memoria, de nuestra identidad y de nuestra historia, porque de eso es de lo que se trata, de justicia" (2012:41).

En estrecha relación con estos resultados obtenemos los resultados que nos muestran el ámbito de acción en el que se presentan los personajes en las láminas propuestas en ambos manuales. Se observa a simple vista, que en el cuadernillo para las niñas hay tres grandes categorías mayoritarias que destacan sobre todas las demás: el ámbito doméstico, el ideológico cultural y el deportivo lúdico. Resulta llamativo que al analizar las láminas, aunque dos de las tres personas que formaban el grupo de discusión eran mujeres, al encontrar personajes femeninos realizando actividades profesionales como la de bailarinas, trapecistas, o nadadoras estas situaciones nunca se valoraran considerándolas una categoría laboral sino se asociaran más bien a una faceta lúdica y deportiva vinculada al ocio o la diversión pero no a una profesión cualificada o digna de insertar en categorías más relevantes. Encontramos también claras diferencias, mientras que en el manual de los niños uno de los ámbitos que más se repite 
Presencia de estereotipos de género en una colección de libros para dibujar

es el militar, en el libro para niñas no hay ninguna acción que se desarrolle en este ámbito reforzando así estereotipos de género que definen a los niños como guerreros, valientes y los encargados de la defensa del grupo mientras las mujeres esperan en el ámbito doméstico, cuidan al guerrero o lo entretienen con sus cánticos, danzas y malabarismos.

\subsection{Adjetivos más frecuentes en los dos libros para dibujar según el género}

Se ha querido completar el análisis del sexismo en la colección de libros para dibujar estudiando en el lenguaje escrito los adjetivos más frecuentes relacionados con la actividad desarrollada por el personaje protagonista en cada uno de ellos. Es decir, en el presente apartado se pretende analizar los adjetivos que califican la cosa o acción que realiza el personaje protagonista. Como previamente se ha señalado, las profesiones, oficios o actividades que desarrollan los hombres o las mujeres tienen una representación distorsionada y sexista sobre el lugar que ocupan en la sociedad. Sin embargo, esta situación se agrava cuando los adjetivos sobre los cuáles recae la actividad del personaje que participa en la acción tienen también un componente sexista.

En primer lugar por ejemplo, al ser nula la representación de la mujer como protagonista en el " $L D O$ ” únicamente se representan adjetivos relacionados con las actividades que realiza el género masculino (Tabla 1). De esta manera, las indicaciones que aparecen en el texto escrito para el libro dirigido a los niños, éstos deben diseñar a través del dibujo "la montaña rusa más escalofriante del mundo", acción en la que de paso, quien tiene el papel protagónico es un hombre. De la misma forma, cuando el libro para niños señala que debe dibujarse un "aparato", la imagen que es protagonizada por un investigador acompañado de otros hombres, el adjetivo que acompaña a la acción es "fantástico". En otra imagen la acción que debe ser realizada por quien dibuja consiste en "diseñar una máquina voladora” y el adjetivo utilizado es "increíble". Además, el presente análisis puede ser completado en la medida en que aquello que "diseña", "construye", "inventa" son "máquinas y aparatos" “castillos" y "robots", respectivamente. Tanto los verbos, los adjetivos y los sustantivos, tienen como personaje protagonista a un hombre, sobre los cuáles recae la acción del personaje que domina la acción o actividad demuestran un conjunto de adjetivos más relacionados con papeles estereotipados del hombre. 
En el " $L D A$ ", cuando se representa una protagonista, el adjetivo utilizado hace referencia a modelos distorsionados (Tabla 1). Por ejemplo, cuando el texto escrito que acompaña la imagen señala la acción de "Diseña la diadema" la diadema que debe ser dibujada deber ser "la más valiosa". En este caso la acción recae no sobre un aparato electrónico y sofisticado que debe ser diseñado por la niña, sino una diadema, instrumento que acompaña la vestimenta femenina. De la misma forma, cuando dos mujeres aparecen representadas en una imagen, el texto escrito que la acompaña y que señala la acción de "hacer" un peinado a una de las "damas", el adjetivo que acompaña el verbo es "ostentoso". Es decir, nuevamente el adjetivo está relacionado con una acción estereotipada hacia el género femenino, que es reforzada además, porque son dos mujeres que portan una vestimenta de fiesta quienes desarrollan la acción una en papel protagónico y la otra en papel secundario. De igual manera, en otra imagen, la acción impuesta por el texto escrito señala que debe dibujarse una playa "paradisiaca" donde la protagonista está ataviada con un traje tradicional con flores.

\subsection{Representación de las órdenes de quien dibuja en los dos libros de texto}

Al analizar los verbos utilizados para dar las órdenes en ambos cuadernillos a las personas que deben realizar las láminas también se observan curiosas diferencias. En el " $L D A$ " los tres verbos más utilizados son, por este orden, "diseñar", “decorar" y "dibujar". Mientras que en el " $L D O$ " son, por este orden, “dibujar", "completar" y "detener". En el primer caso, todos los verbos inciden en la faceta creativa de las niñas animándolas a desarrollar sus habilidades ornamentales y de creación de prendas textiles o elementos de adorno.

En los verbos del " $L D O$ ” hay coincidencia al encontrar también la acción de dibujar como destacada en ambos casos, lo que se explica por el objetivo mismo de este tipo de libro de entretenimientos. Luego con el verbo que aparece en segunda posición "completar" se observa como el manual en sus instrucciones incita a los pequeños a realizar tareas complejas y ser activos y emprendedores, pero sobre todo las diferencias se acentúan al encontrar como tercer verbo "detener" que presupone una autoridad o capacidad de manda para prender a alguien o interrumpir algo.

Pero es quizá en las ausencias, o en las diferencias de verbos utilizados, donde vemos matices más interesantes. En el libro para niños aparecen verbos como inventar, arreglar, chutar, conseguir, disfrazar y detener que no aparecen en el libro para niñas. Muchos de estos 
Presencia de estereotipos de género en una colección de libros para dibujar

verbos llevan implícito el esfuerzo, el mérito, la habilidad técnica, fuerza física o destreza mental. El lenguaje utilizado en este cuaderno es mucho más rico, en lo que a número de verbos diferentes utilizados se refiere, lo que aumenta el registro y el tipo de órdenes recibidas por los niños frente al cuaderno para niñas. En el caso de las niñas, el único verbo equiparable que podemos encontrar, y que no aparece en el de niños, es “construir". Los otros dos verbos exclusivos de este manual son "pintar", lo cual limita la creatividad del sujeto a rellenar un dibujo ya dado o "mostrar" que recuerda esa tendencia de utilizar a la mujer en papeles pasivos de posado frente a la actividad e iniciativa masculina. Además, aquellas órdenes del texto escrito como "diseña", "construye" o "haz" entre otros, hacen referencia a "diademas y uniformes", "muñecos de nieve" y "peinados", respectivamente.

\section{Conclusiones}

El principio del sistema educativo español que consiste en el desarrollo de la igualdad de derechos y oportunidades y el fomento de la igualdad efectiva entre hombres y mujeres, atraviesa la necesaria reflexión y puesta en la mira sobre aquellos materiales educativos que promueven estereotipos sexistas y que fomentan la discriminación hacia las mujeres. El equipo de investigación que ha desarrollado el presente estudio considera que, con base en las conclusiones que a continuación reseñamos, y de acuerdo a las hipótesis planteadas al inicio del estudio, se corrobora que en el “ $L D O$ ” los hombres y los niños tienen una representación predominante en las imágenes, mientras que las mujeres y las niñas son absolutamente silenciadas o aparecen en ámbitos domésticos y excluidas de una proyección y desarrollo profesional equivalente a la de sus homólogos. Aparecen relegadas de los ámbitos de vida social más relevantes y decisorios lo que se concreta en una falta de oportunidades o mayores dificultades para avanzar en su carrera profesional.

La edad de los personajes protagonistas y secundarios en las imágenes tienden a una representación mayor de hombres adultos y una baja representación de personas mayores, adolescentes e infantes. Por su parte en el " $L D A$ " las mujeres y las niñas tienen una representación predominante en las imágenes, mientras que los hombres sí son representados incluso como personajes protagonistas. La edad de los personajes protagonistas y secundarios, tienden a representar en equilibrio a mujeres adultas, adolescentes y niñas, observándose una 
tendencia a representar más a mujeres en edad adolescente e infantil diferente a la planteada por el “ $L D O$ ”. Lo cual, recupera los modelos estereotipados más mediáticos y publicitarios de la mujer donde la juventud es un valor en alza que oculta a las mujeres a medida que avanzan en edad considerando que se produce así una depreciación de dicho género.

De la misma forma, en el texto escrito se observa que el " $L D A$ ” utiliza verbos que reafirman estereotipos de género en contra de las mujeres como "Decorar" y "Diseñar" mientras que los verbos en el " $L D O$ " reafirman actitudes de dirección y liderazgo que están relacionadas con ámbitos y profesiones estereotipadas del género masculino como inventores, científicos y militares. Lo cual viene a insistir en esa separación de esferas y mundos en que ambos se mueven e incluso condiciona la elección de la profesión a rasgos inherentes al género como son las profesiones más bohemias y creativas a las mujeres y la producción científica, tecnológica o defensiva a los hombres.

De la misma manera, en el lenguaje escrito, los adjetivos utilizados para retratar la acción de los personajes principales refuerzan la representación de roles estereotipados de género al fomentar las habilidades ornamentales y decorativas de las protagonistas " $L D A$ ” con las láminas enfocadas a fomentar el culto al cuerpo que refuerza el estereotipo de que la mujer debe destacar y priorizar sus atributos físicos frente a una utilización en el " $L D O$ ” que ensalza las habilidades intelectuales o creativas de los niños.

Por el contrario, se observó que salvo la representación dominante del género femenino y masculino en el " $L D A$ ” y en el " $L D O$ ” respectivamente, tanto las mujeres como los hombres estuvieron representados de manera individual o colectivamente, sin observarse diferencia entre los dos libros.

En definitiva, ambos libros hacen un uso de las imágenes utilizando roles estereotipados que afectan sobre todo a la forma de retratar a hombres y mujeres. Lo que evidenciaría que este tipo de materiales, condicionan y trasmiten conductas estereotipadas con respecto al desarrollo profesional de las personas vinculado a su género. Teniendo en cuenta que la creación de la identidad de género se produce en la primera infancia, es sumamente importante utilizar unos materiales que busquen el equilibrio y la igualdad. De esta manera, la identidad de género y la comprensión y adaptación al entorno social se conseguirá un desarrollo personal en los niños y niñas con un espectro ampliado de roles de género que facilitará la consecución de una igualdad real. 


\section{BIBLIOGRAFÍA}

- Blanco García, Nieves e Instituto Andaluz de la Mujer (2000). El sexismo en los materiales educativos de la ESO. Sevilla: Instituto Andaluz de la Mujer.

. (2003): "La imagen del mundo: la representación de mujeres y varones en textos de Educación Secundaria Obligatoria”. En: Villuendas, M ${ }^{\mathrm{a}}$ D. y. Gordo, A. J. (coord.): Relaciones de género en psicología y educación. Madrid: Consejería de Educación, pp. 31-46.

- Brugelles, Carole y Sylvie Cromer (2009). En: UNESCO (ed.). Promoting gender equality through textbooks. A methodological guide. 1st ed., France: United Nations Educational, Scientific and Cultural Organization.

- Cabrera, Yolanda (2009): Publicidad e industria cultural. Las marcas y la representación de género. Valencia: Universitat de València.

- Federación de Gremios de Editores de España, FGEE (2011): International Book Industry Categories (IBIC). Sistema de clasificación de materias. Versión 1.1 Revisión 1 en español (octubre 2011), basada en la v. 2.1 inglesa.

- García-Gracia, Maribel et al. (1993): El sexismo en los libros de texto: Análisis y propuesta de un sistema de indicadores. Madrid: Instituto de la Mujer.

- Garreta, Nuria y Careaga, Pilar (1987): Modelos masculino y femenino en los textos de E.G.B. Madrid: Serie Estudios 14.

- Giroux, Henry (1992): Teoría y resistencia en educación: una pedagogía para la oposición. México: Siglo XXI.

- Gutiérrez Sánchez, Judit (2012): "Presencia y tratamiento de la mujer en los libros de texto. ¿Invisibilidad, transversalidad o patchwork políticamente correcto? Análisis y reflexión”. Trabajo Final de master en formación del profesorado en Secundaria. Universidad de Cantabria, [en línea] Disponible en http://repositorio.unican.es/xmlui/bitstream/handle/10902/1694/Guti\%C3\%A9rrez\%20S\%C3\% A1nchez,\%20Judit.pdf?sequence=1 [26/12/2013].

- Hsieh, Hsiu-Fang y Shannon, Sarah E. (2005): Three approaches to qualitative content analysis. Qualitative health research, $\mathrm{n}^{\mathrm{o}} 15$ (9), pp. 1277-1288. 
- Instituto de la Mujer e IMOP Encuestas, S. A. (2000): La transmisión de los modelos femenino y masculino en los libros de la enseñanza obligatoria. Madrid: Instituto de la Mujer.

- Ley Orgánica 1/2004, de 28 de diciembre, de Medidas de Protección Integral contra la Violencia de Género (2004).

- Ley Orgánica 2/2006, de 3 de mayo, de Educación (2006).

- Ley Orgánica 3/2007, de 22 de marzo, para la igualdad efectiva de mujeres y hombres (2007).

- Martínez Bello, Vladimir (2013): "Representación racial, diversidad corporal y género en las imágenes de libros de texto españoles de educación infantil”. En: Diálogos sobre educación. Temas actuales en Investigación Educativa, nº 4 (7), pp. 1-17.

(2013a): "Las posibilidades de movimiento del cuerpo infantil en las imágenes de libros de texto de educación infantil". En: RELAdEI. Revista Latinoamericana de Educación Infantil, n² (3), pp. 177-190.

- Fitzpatrick, Maureen y McPherson, Barbara (2010): “Coloring within the lines: Gender stereotypes in contemporary coloring books”. En: Sex Roles, nº 62 (1-2), pp. 127-137.

- Michel, Andrée (1987): Fuera moldes: hacia una superación del sexismo en los libros infantiles y escolares. Organización de las Naciones Unidas para la Educación, la Ciencia y la Cultura.

- Ministerio de Educación, Ciencia y Cultura. España (2013): El sector del libro en España 2011-2013. Observatorio de la Lectura y el Libro del Ministerio de Educación, Cultura y Deporte. 2013.

- Neuendorf, Kimberly (2011): “Content analysis-A methodological primer for gender research”. En: Sex Roles, nº 64 (3-4), pp. 276-289.

- Pellejero Goñi, Lucía, y Torres Iglesias, Blanca (2011): "La educación de la sexualidad: El sexo y el género en los libros de texto de educación primaria”. En: Revista De Educación, nº 354, pp. 303-304.

- Peñalver, Rosa (2003): ¿Qué quieres enseñar? Un libro sexista oculta a la mitad. Murcia: Instituto de la Mujer.

- Pinder, Andrew (2010): Doodles para niñas. España: Pirueta. . (2010a): Doodles para niños. España: Pirueta. 
Presencia de estereotipos de género en una colección de libros para dibujar

- Rachlin, Susan y Vogt, Glenda (1974): "Sex roles as presented to children by coloring books". En: The Journal of Popular Culture, n VIII (3), pp. 549-556.

- Randall, Ashley y Draper, Thomas (1981): “Coloring-book-type experiences and children's divergent pictorial production”. En: Journal of Applied Developmental Psychology, n 2 (4), pp. 297-307.

- Organización de las Naciones Unidas (2000): Resolución 55/2 del 13 septiembre 2000. Asamblea general de las Naciones Unidas. Declaración del Milenio. Cap. III, 19.

- Sacristán, José Gimeno (1991): “Los materiales y la enseñanza”. En: Cuadernos de Pedagogía, no 194, pp. 10-15.

- Stokely, Michelle (2010): “Tipis, Ponies and Little Dancing Braves: Imagining Native American Culture through Children's Coloring Books". En: Journal for the Liberal Arts and Sciences, $\mathrm{n}^{\circ} 15$ (1), pg. 77.

- Subirats, Marina (2007): “Coeducación y violencia de Género”. En Gairín, J. y Rifá, J. (coord.): Coeducar y prevenir la violencia de género. Madrid: Escuela Española.

- Taboas Pais, María Inés y Rey Cao Ana Isabel (2012): “Gender differences in physical education textbooks in Spain: A content analysis of photographs". En: Sex Roles, $n^{o} 67$ (7-8), pp. 389-402.

- Terrón Caro, María Teresa y Verónica Cobano-Delgado Palma (2008): "El papel de la mujer en las ilustraciones de los libros de texto de educación primaria". En: Foro De Educación, n 10 , pp. 385-400.

. (2009): "El papel de la mujer en las imágenes de los libros de texto de educación primaria. Estudio comparado entre españa y marruecos". En: Educatio Siglo XXI: Revista De La Facultad De Educación, nº 27, pp. 231-248.

- Weitzman, Lenore J.; Deborah Eifler, Elizabeth Hokada y Catherine Ross (1972): "Sex-role socialization in picture books for preschool children". En: American Journal of Sociology, $\mathrm{n}^{\circ}$ 77 (6), pp. 1125-1150. 